\title{
Nursing Process Supported by Expert System in the Application of the Glasgow and Braden Scales in a Brazilian Public Hospital
}

\section{Processo de Enfermagem Apoiado por Sistema Especialista na Aplicação das Escalas de Glasgow e Braden em um Hospital Público Brasileiro}

\author{
Edquel Bueno Prado Farias Universidade Anhembi Morumbi-edquel.prado@anhembi.br \\ https://orcid.org/0000-0002-7490-8148 \\ Dacyr Dante de Oliveira Gatto Universidade Nove de Julho - Brasil. dacyrgatto@terra.com.br \\ https://orcid.org/0000-0003-2146-4819 \\ Marcio Romero Universidade Nove de Julho - Brasil. mhromero@hotmail.com \\ https://orcid.org/0000-0001-7595-9249 \\ Maria Luiza Almeida de Oliveira Moura Universidade Nove de Julho - Brasil. luizaleyd_@uni9.edu.br \\ https://orcid.org/0000-0003-3767-970X \\ Renato José Sassi Universidade Nove de Julho - Brasil. sassi@uni9.pro.br \\ https://orcid.org/0000-0001-5276-4895
}

\section{RESUMO}

O processo de enfermagem padroniza a forma de atender e diagnosticar o paciente e, durante sua execução, escalas de apoio são utilizadas, como a de Glasgow e de Braden, que visam agregar parâmetros na decisão clínica. Para apoiar a aplicação correta dessas escalas, é possível utilizar técnicas da Inteligência Artificial (IA), como os Sistemas Especialistas (SE). O hospital público, objeto de estudo deste trabalho, não apresentava o processo de enfermagem informatizado e nem um SE. Desta forma, informatizou-se o processo, e um SE foi usado para auxiliar na aplicação das escalas. O objetivo deste trabalho, então, foi apresentar a implementação, em hospital público, do processo de enfermagem apoiado por SE na aplicação das escalas de Braden e Glasgow. A metodologia de pesquisa adotada foi bibliográfica, aplicada e experimental. O processo de coleta e validação dos dados desse estudo foi obtido a partir de entrevista dos enfermeiros envolvidos no processo e na validação e aprovação da base de conhecimento do SE pelos especialistas, tanto do hospital quanto dos contratados para consultoria externa. Com a aplicação do processo de enfermagem informatizado, padronizou-se o atendimento hospitalar, normalizando os processos relativos à enfermagem e, assim garantindo assertividade do enfermeiro no processo de tomada de decisão. Conclui-se que a implementação do processo de enfermagem informatizado apoiado pelo SE apoiou a tomada de decisão no hospital.

Palavras-chave: Processo de Enfermagem Informatizado; Sistemas Especialistas; Escala de Glasgow; Escala de Braden.

\begin{abstract}
The nursing process standardizes the way to assist and diagnose the patient and during its execution, support scales are used, such as the Glasgow and Braden scales, which aim to aggregate parameters in the clinical decision. To support the correct application of these scales, it is possible to use Artificial Intelligence (Al) techniques, such as Expert Systems (ES). The public hospital, the object of this study, did not have a computerized nursing process or an ES. In this way, the process was computerized, and an ES was used to assist in the application of the scales. The objective of this work, then, was to present the implementation, in a public hospital, of the nursing process supported by ES in the application of the Braden and Glasgow scales. The research methodology adopted was bibliographic, applied and experimental. The data collection and validation process of this study was obtained from interviews with nurses involved in the process and in the validation and approval of the SE knowledge base by specialists, both from the hospital and from those hired for external consultancy. With the application of the computerized nursing process, hospital care was standardized, normalizing the processes related to nursing and thus guaranteeing the nurses' assertiveness in the decision-making process. It is concluded that the implementation of the computerized nursing process supported by the ES supported decision making in the hospital.
\end{abstract}

Keywords: Computerized Nursing Process; Expert Systems; Glasgow Scale; Braden Scale. 


\section{INTRODUCTION}

The Nursing Process (NP) is a methodological instrument that favors quality and safety in patient care. For its implementation, nurses need to consult a wide range of literature and technical-scientific support material, which requires a lot of research time for each diagnostic and prescription item (RAMOS; RODRIGUES; GONZAGA, 2018).

Palomares and Marques (2010) and Domingos (2017) mention that, when computerizing the nursing process, the main contributions are: time optimization, better organization, language standardization, decision-making aid, ease of data retrieval and multi professional communication, less redundancy, information integration as well as data security and integrity.

Importantly, during the development of the nursing process, scales are used, such as Glasgow and Braden's, to aggregate parameters in clinical decision (diagnosis), evolution and patient history (RAMOS; RODRIGUES; GONZAGA, 2018; WECHI et al., 2017; OLIVEIRA; DIAS; SOUSA, 2018).

The Glasgow Coma Scale (GCS), also known as the Glasgow Scale, is an essential tool for measuring a patient's level of consciousness as it assesses their ability to open their eyes, communicate verbally, obey commands and move their extremities. For this reason, it has been used both in prehospital care and in Intensive Care//Units (ICU) (SURABENJAWONG; SONMEETHONG; NAKORNCHAI, 2017).

The Braden scale is an essential instrument to measure the risk of developing pressure ulcer, which is defined as an injury caused by unrelieved pressure, resulting in decreased blood circulation and, consequently, death and skin necrosis. (PEREIRA; LUDVICH; OMIZZOLO, 2016; WECHI et al., 2017).

To support decision making and application of the Glasgow and Braden scales, the Artificial Intelligence (Al) technique called the Expert System (ES) can be used. (PEEK et al., 2015).

An ES deals with real-world problems that would most often require expert analysis and interpretation. Using a computer model analogous to human reasoning, it is possible to reach conclusions like those of a subject matter expert (MAGOC; MAGOC, 2011).

One of the differences between an ES and a database program is the use of logical reasoning, using inference procedures for problem solving. ES use "IF THEN" probability and production rules, followed by related logical connectors within the scope of the issue at hand (ESFANDIARI et al., 2014).

Thus, the aim of this paper was to present the implementation, in a Brazilian public hospital, of the nursing process supported by the ES in applying the Glasgow and Braden scales.

\section{LITERATURE REVIEW}

This section presents the literature review used in this paper where the themes Nursing Process, Supporting Scales and Expert System were addressed.

\subsection{Nursing Process}

The Nursing Process (NP) emerged in the 1960, based on the scientific method of observation, measurement, and data analysis, being described by Virginia Henderson and elaborated by Faye Abdellah (ALFARO-LEFEVRE, 2014).

In 1979, in Brazil, the nurse Wanda de Aguiar Horta presented and defined the NP as the dynamics of systematized and interrelated actions aimed at assisting human beings, based on the theory of basic human needs (Horta, 2011). The NP, however, only began to be implemented in health institutions in 2009, meeting the requirements of the Federal Nursing Council (COFEN, 2009).

According to Resolution 358/2009 (COFEN, 2009), the NP should be carried out throughout Brazil, deliberately and systematically, by all public and private health institutions. A well-known and used synonym for NP is the Nursing Care Systematization (NCS) (ALFARO-LEFEVRE, 2014).

The nursing process can be seen as a set of systematic and interrelated actions, aimed at assisting human beings. It is characterized by the interrelationship and dynamism of its phases and steps. 
Also, according to resolution 358/2009 (COFEN, 2009), the NP is organized in 5 steps: a) Collection of nursing data or nursing history; b) Nursing diagnosis; c) Nursing planning; d) Nursing implementation; e) Nursing assessment.

The following steps of the NP are described:

a) Nursing Data Collection or Nursing History

It consists of interview and physical examination. The interview will investigate the patient's or community's health situation, identifying problems and needs for interventions. The physical examination consists of inspection, palpation, percussion and auscultation, procedures that require theoretical knowledge and appropriate technical skills to perform.

b) Nursing Diagnosis

At this stage, the nurse analyzes the collected data and the individual's health status through the identification and evaluation of present or potential health problems. The diagnoses are made according to the protocols of the institution; the most used are North American Nursing Diagnosis Association (NANDA) and CIPE.

c) Nursing Planning

Specific expected outcomes are determined, and necessary interventions identified. Interventions should be targeted to achieve estimated outcomes as well as to prevent, resolve or control changes encountered during nursing history and diagnosis.

d) Nursing Implementation

It is the implementation of the care plan and the implementation of actions or interventions determined in the nursing planning stage.

e) Nursing assessment

Systematic and continuous process of verification of changes in the responses of the person, family or community at a given time in the health-disease process to determine if nursing actions or interventions have achieved the expected result. Here, there is also the need for changes or adaptations in any of the NP steps. The following indicators are used for assessment: Missing or Present; Better or Worse; Maintained or Resolved. This stage is the evolution of nursing, which is the patient's assessment every 24 hours (RAMOS; RODRIGUES; GONZAGA, 2018).

The interrelationship between these phases is fundamental. Therefore, improper data collection can lead to erroneous conclusion of the problems presented and improper planning (DA SILVA REIS et al., 2016).

The nurse should know and use various literature on nursing classification systems during the elaboration of NP. Among them are the following classifications suggested by NANDA (KIM et al., 2018; LUCENA et al., 2018): the Nursing Interventions Classification (NIC) (BUTCHER et al., 2018; KIM et al., 2018; LUCENA et al., 2018); the Nursing Outcomes Classification (NOC) (MOORHEAD; JOHNSON; MAAS; SWANSON, 2015); and the International Classification for Nursing Practice (ICNP) (GARCIA et al., 2020).

NANDA, in conjunction with NIC and NOC, provides the nursing discipline with the elements of clinical data for automated patient registration (MOORHEAD; JOHNSON; MAAS; SWANSON, 2015; KIM et al., 2018; LUCENA et al., 2018). NANDA is a must-have literature composed of a compilation of nursing diagnoses that describes patients' reactions to disease (BUTCHER et al., 2018; KIM et al., 2018).

$\mathrm{NIC}$ is a comprehensive and standardized classification of interventions performed by nurses and is responsible for characterizing hospital interventions in a very specific way. The NOC measures changes in patient status, i.e., documents the development of standardized results for disease assessment (BUTCHER et al., 2018; LUCENA et al., 2018). 


\subsection{Supporting Scales}

During the NP stages, the Glasgow and Braden scales are used to measure values that support diagnosis and prescription. The Braden Scale is an essential instrument for measuring the likelihood of patients developing pressure ulcers. It was published in 1987 in the United States and was adapted and validated for Brazilian culture in 1999 (PEREIRA; LUDVICH; OMIZZOLO, 2016; OLIVEIRA; DIAS; SOUSA, 2018; WECHI et al., 2017).

The Braden scale is composed of six subscales (Gomes et al., 2011; WECHI et al., 2017): Sensory perception, activity, mobility, nutrition, friction and shear. All contribute to the development of pressure ulcers and none of them should preferably be evaluated over another (RITROVATO et al., 2015; OLIVEIRA; DIAS; SOUSA, 2018.

The six subscales receive a score according to the commitment presented. To evaluate each of them one must resort to the definition of the parameters included in the scale. Scores range from 1 to 4 , except for the "friction" and "shear" subscales, which range from 1 to 3 . The sum of the six subscales ranges from 6 to 23 . The lower the value, the greater the compromise presented and, consequently, the greater the risk exposure (OLIVEIRA; DIAS; SOUSA, 2018). Table 1 shows the Braden Scale.

Table 1 - Braden Scale

\begin{tabular}{lllll}
\hline Description & $\mathbf{1}$ & $\mathbf{2}$ & $\mathbf{3}$ & $\mathbf{4}$ \\
\hline Sensory perception & $\begin{array}{l}\text { Totally } \\
\text { limited }\end{array}$ & Very limited & $\begin{array}{l}\text { Slightly } \\
\text { limited }\end{array}$ & No limitation \\
\hline Moisture & $\begin{array}{l}\text { Completely } \\
\text { wet }\end{array}$ & Very wet & $\begin{array}{l}\text { Occasionally } \\
\text { wet }\end{array}$ & Rarely wet \\
\hline Activity & Chained & $\begin{array}{l}\text { Confined to } \\
\text { Chair Walks }\end{array}$ & Occasionally & $\begin{array}{l}\text { Walks } \\
\text { Frequently }\end{array}$ \\
\hline Mobility & Totally & Very limited & $\begin{array}{l}\text { Lightly } \\
\text { limited }\end{array}$ & $\begin{array}{l}\text { No } \\
\text { limitations }\end{array}$ \\
\hline Nutrition & Very poor & $\begin{array}{l}\text { Probably } \\
\text { inadequate }\end{array}$ & Adequate & Excellent \\
\hline $\begin{array}{l}\text { Friction and } \\
\text { Shearing }\end{array}$ & Problem & Potential & Problem & No Problem \\
\hline
\end{tabular}

Source: COFEN (2009).

Patients with a score equal to or greater than 16 points are considered to be at low risk for developing pressure ulcers. Score between 11 and 16 indicates moderate risk, and below 11 points indicates high risk, as it shows that there was a significant organic functional decrease that facilitates the onset of decubitus ulcer (GOMES et al., 2011; WECHI et al., 2017).

Another support scale used is the Glasgow Scale, an essential instrument for measuring the patient's level of consciousness, as it assesses their ability to open their eyes, communicate verbally, obey commands and move their extremities. It is commonly used in both prehospital care and intensive care units.

The Glasgow Scale was developed and published in Lancet magazine in the 1970s by Graham Teasdale and Bryan Jennett. Its initial version was named Coma Index (CI), but after a statistical study of the scoring system, it became the Glasgow Coma Scale (GCS) (TEASDALE; JENNETT, 1974; TEASDALE; MURRAY, 2000; SURABENJAWONG; SONMEETHONG; NAKORNCHAI, 2017).

In Table 2, this scale is illustrated. 
Table 2 - Glasgow Coma Scale (GCS)

\begin{tabular}{ccc}
\hline & Glasgow Coma Scale & \\
\hline \multirow{2}{*}{ Eye opening } & Variables & Score \\
& Spontaneous & 4 \\
& The voice & 3 \\
& No pain & 2 \\
\hline Verbal Answer & Oriented & 1 \\
& Confused & 5 \\
& Inappropriate words & 4 \\
& Incomprehensible words & 3 \\
& None & 2 \\
\hline Motor Response & Obey commands & 1 \\
& Finds pain & 6 \\
& Withdrawal movement & 5 \\
& Abnormal flexion & 4 \\
& Abnormal extension & 3 \\
& None & 2 \\
\hline $\mathbf{1 5}$ & Minimum Total & 1 \\
\hline & $\mathbf{3}$ & $\mathbf{8}$ \\
\hline
\end{tabular}

Glasgow Scale findings form the basis of clinical decision making, such as the need for computed tomography, surgical intervention and / or drug modality (SURABENJAWONG; SONMEETHONG; NAKORNCHAI, 2017).

\subsection{Expert System}

Expert System (ES) is an Artificial Intelligence (Al) technique that emulates the behavior of human experts in their domain to solve complex problems that require intensive use of specialized knowledge for their solution (WAGNER, 2017).

For Weiss and Kulikowski (1988), ES deals with complex real-world problems that would usually require expert analysis and interpretation, and solves them through a reasoned computational model of a human being in order to arrive at the same conclusions as that of a subject matter expert.

An ES consists in structuring the knowledge and experiences of human specialists through a computational representation that allows the application of consistent computer processing methods (DYMOVA; SEVASTJANOV; KACZMAREK, 2016).

To assist in the construction of ES, knowledge-oriented tools called shells were created. A shell allows the system developer to worry only about the knowledge representation of the expert, leaving it to the task of interpreting the knowledge represented and executing it on a machine. In addition, the shell provides explanations of how the system reaches a certain conclusion (NASER et al., 2016). Thus, an ES has two essential components in its architecture: the knowledge base (where knowledge is stored) and the Inference engine (where the inference or deduction process occurs). 
The typical architecture of an ES, in addition to the knowledge base and inference engine, contains the user interface and the acquisition interface and the explanation module, as can be seen in Figure 1. Importantly, not all ESs have the same structure, but overall, it is quite similar (GUPTA; SINGHAL, 2013).

Figure 1 - Architecture of an ES

\section{Expert System Architecture}

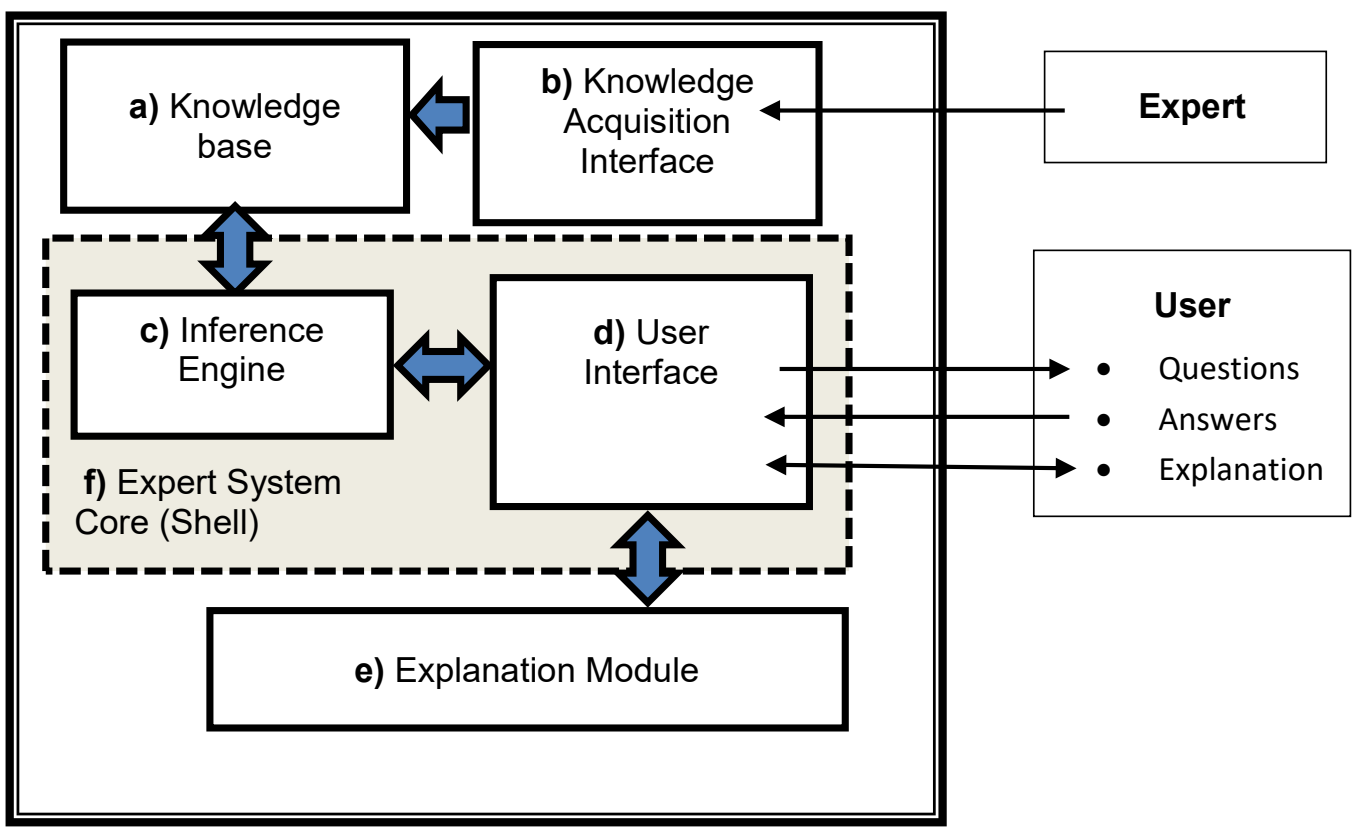

Source: Adapted from Gupta and Singhal (2013).

The following is a description of the modules presented in Figure 1 (GUPTA; SINGHAL, 2013)

a) Knowledge Base: is the module where the system knowledge is stored; Its creation is the first step in the development of an ES. It can be said that the great power of an ES lies in its knowledge base, since it contains the knowledge concerning the domain of the problem to be solved by the expert, which will be used in the decisions regarding the application domain. The basis is the rules and facts of problem solving, that is, it is like the intuition that a human expert can use to solve problems in a domain. It can be stated that the rules and facts contained in the knowledge base is the representation of all knowledge acquired from human specialists. Such knowledge can be represented in various forms, namely: production rules, logic, or semantic networks.

b) Knowledge Acquisition Interface: Used to add, modify, and update facts, attributes, and rules contained in the knowledge base. This part of the ES interacts directly with the human expert and can be brokered by a knowledge engineer who is responsible for its extraction and representation. The process of changing the knowledge base can be something simple, such as adding data, or more complex, such as debugging the base, reordering priorities, among others.

c) Inference Engine: Is responsible to access the knowledge base and decision making. To do this, it applies the knowledge contained in the knowledge base, relying on user input and knowledge base rules to reach any solution or conclusion. The Inference Engine is the central part of an ES, responsible for the interaction between the user and the ES during a query. It can be said to be the algorithm used to search the knowledge base. The Inference Engine assesses the knowledge of the base and then directs the resolution process. There are several formalities to implement the inference, research and conclusion process. The most used are forward chaining and backward chaining. The inference engine drives the ES to the expected solution, linking, in the case of the rule-based system, these to the facts. 
d) User interface: Also known as data collection module; is the module responsible for the interaction between the ES and the user. This interaction can be console based (text) or graphical interfaces (multiple choice windows). Preferably, one should interact with the user, using natural language, in such a way that the user interacts with the ES just as he would with a human expert. It is through this interface that the user proceeds to input data, entering answers to system questions and receiving explanations regarding queries made to the ES.

e) Explanation Module: Has the function of justifying the reasoning used by the ES and it is a mandatory requirement. The Explanations Module usually provides a history, explaining step by step how the ES reached a certain conclusion, why the ES reached that conclusion, and why the ES did not reach another conclusion. To this end, the Explanation Module determines in detail how and which rules were accepted and which were rejected. Therefore, the Explanation Module is extremely important for the user to understand what was the reasoning used by the ES to arrive at a particular solution about a particular decision, or about any fact or knowledge that he has stored in the base.

f) Expert System Core (Shell): The main feature of an ES is the separation between the Knowledge Base and the Inference Engine. This separation makes it possible to represent knowledge through IF-THEN rules, which are closer to human thinking. It also allows the same inference engine to be used to find the solution in ESs with different knowledge bases; It also allows the knowledge base to be changed without changing the algorithm used in the Inference Machine. The set formed by the Inference Engine and User Interface is known as the ES Core or Shell.

The ES can be applied in several areas and are based on assisting in problem solving and diagnostics, through questions directed to users, which are based on decision rules elaborated through the acquisition of knowledge from experts in the studied area. From the users' answers, the system, through its inference engine, gives the user a possible solution (MILLER et al., 2015, PANNU, 2015).

Some examples of the application of ES in healthcare are: AIDS treatment aid (SOUZA, 2020), prostate cancer diagnosis (PEREIRA; SCHAEFER; MARQUES, 2004; NIKITAEV, 2018), dengue symptom analysis (HAIKAL, 2017), HPV Risk Prediction (DRABLE; MOL; LEGEY, 2014) and Diagnosis of Blood Infections (SHORTLIFFE, 2019).

It is worth highlighting the work of Wagner (2017) conducted robust research by collecting 311 case studies on the use of higher education in various areas of knowledge between 1984 and 2016. The study shows that the application of higher education went from medicine to several other areas of knowledge.

\section{MATERIALS AND METHODS}

The research methodology adopted in this work was defined as bibliographic, exploratory and experimental, with quantitative approach. The research can also be considered as applied, since it aims to generate knowledge and use it in a practical way, considering the results obtained (GIL, 2016).

The experimental research was performed in 5 steps described below:

Step 1: The Access application was used to create and normalize the database, which, in this case, are evaluation protocols based on the Glasgow and Braden Scales. The task of data acquisition was done from spreadsheets, books, interviews and gathering prior knowledge of hospital specialists.

Step 2: Data were selected and preprocessed with Excel.

Step 3: The data were evaluated and validated by experts in the domain.

Step 4: The computerized nursing process was implemented.

Step 5: ES was implemented to support decision making, using the Expert Sinta, developed by the Laboratório de Inteligência Artificial (LIA, 1999) of the Universidade Federal do Ceará. ES offers an inference engine. With the help of the shell, the production rules were inserted into the rule base and knowledge.

As already mentioned, the following steps of the NP are: Nursing Data Collection or Nursing History; Nursing Diagnosis; Nursing Planning; Nursing Implementation and Nursing assessment.

The computerization of the nursing process aims to make the collection, treatment and use of these data as accurate as possible. The ES stands out to support decision-making in raising patient signs and 
symptoms with the Glasgow and Braden scales. Next, in Figure 2, we present the components and steps of the computerized nursing process.

Figure 2 - Steps of the Computerized Nursing Process

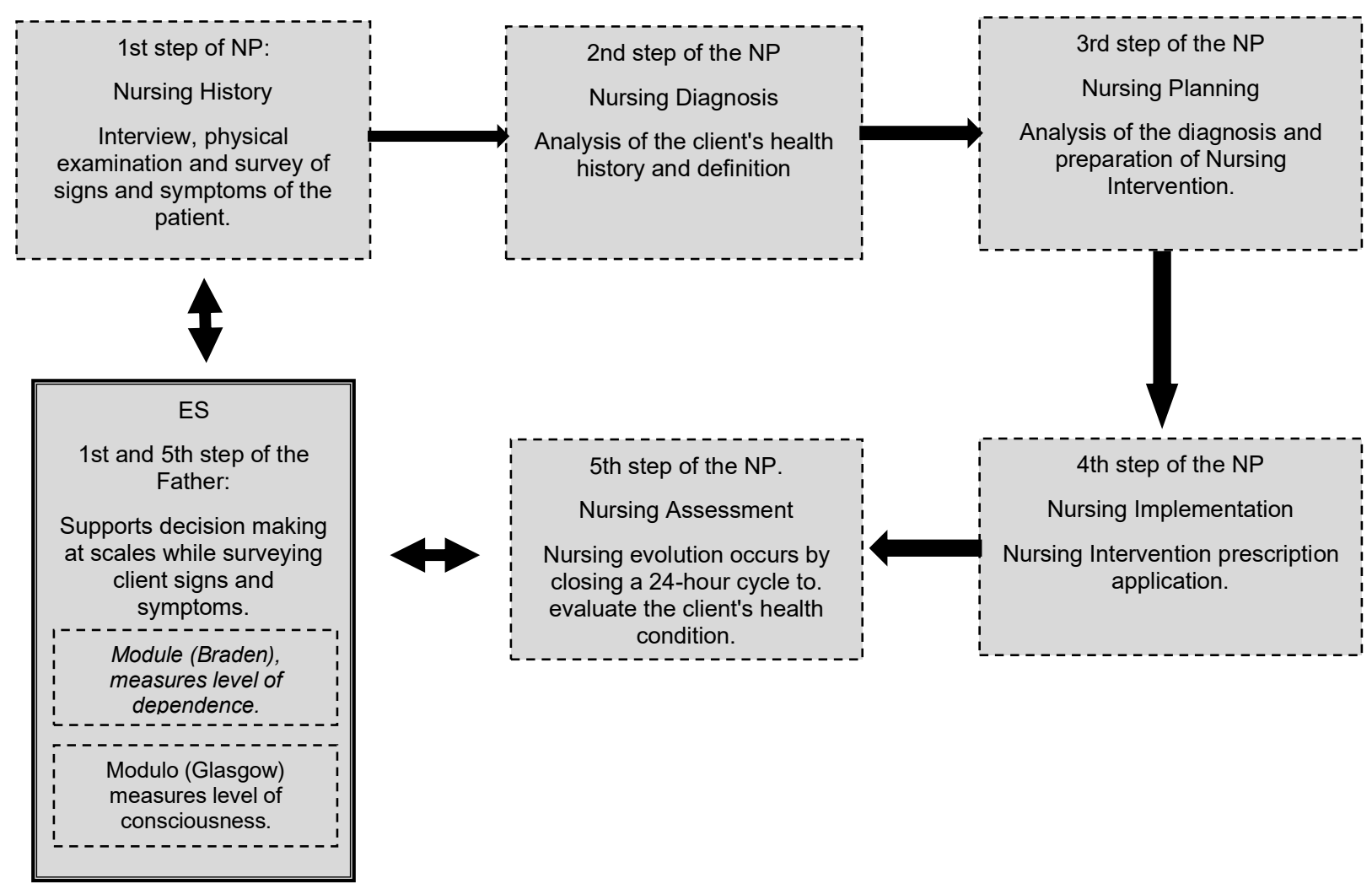

Source: Authors (2019).

\section{RESULTS DISCUSSION}

As shown in Figure 3, the initial interface of the computerized nursing process consists of the following subsystems: patient registration, diagnosis, evolution and nursing history, view prescription and end NP.

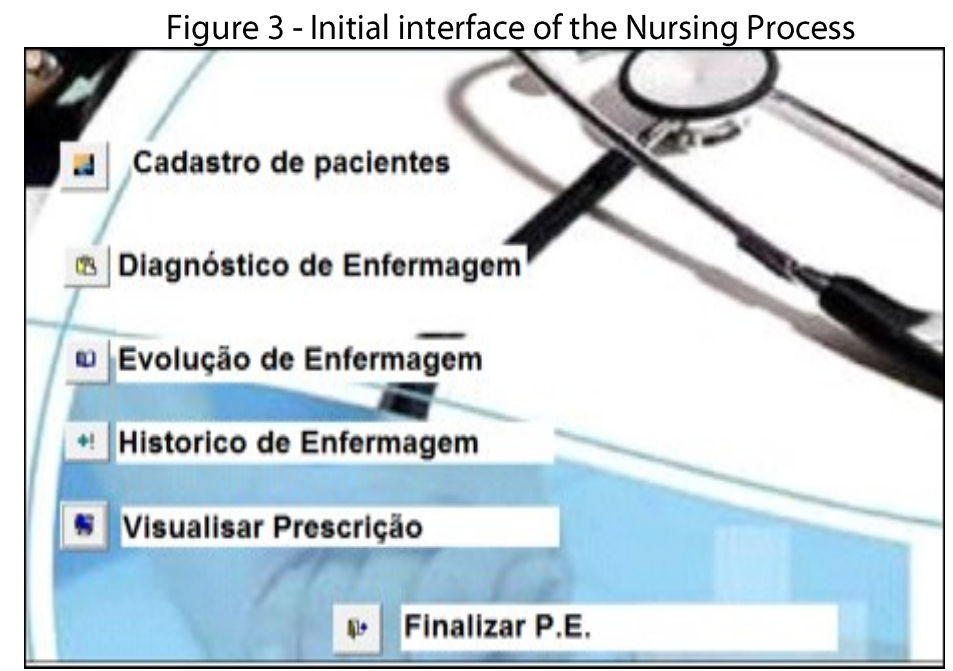

Source: Authors (2019). 
With the help of the shell, the production rules were inserted in the rule base and knowledge, as shown in Figure 4.

Figure 4 - Example of rule generated by ES.

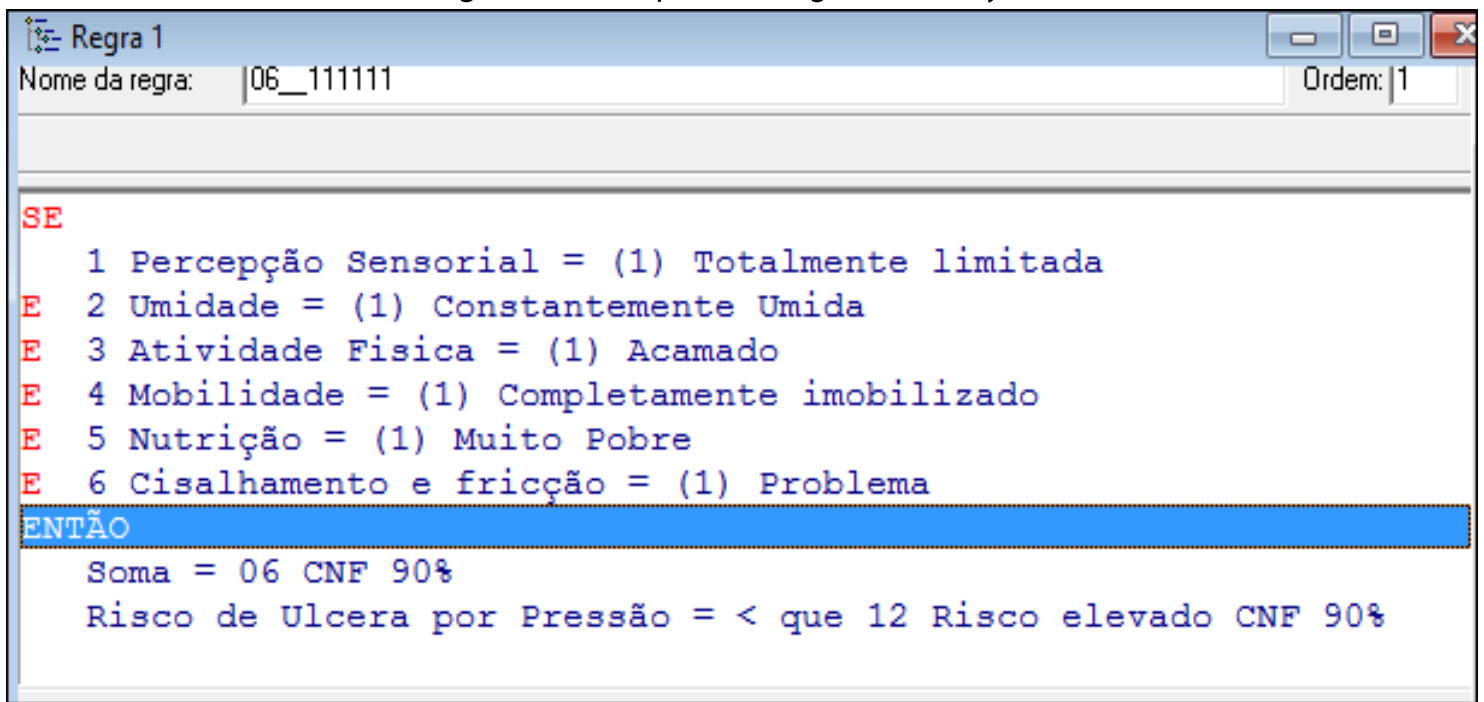

Source: Authors (2019)

During the evolution of the NP, it is possible to access the window of signs and symptoms. To fill it out, the specialist consults the interface of an ES (Glasgow and Braden Scales) that provides support for nurses' decision making.

The ES consists of two main modules: Glasgow and Braden scale. Both were developed with the application of ES. While using the Braden Scale module, the user visualizes the question interface, which opens new windows until all conditions are fulfilled to answer the question raised, as shown in Figure 5.

Figure 5 - ES Question Interface Braden Scale

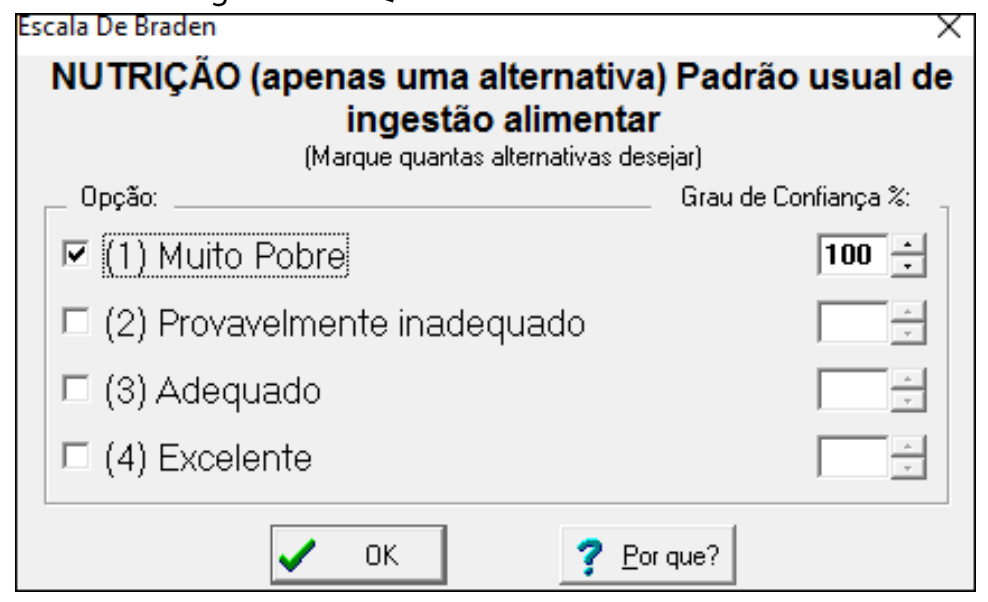

Source: Authors (2019).

Inferring at the end of this process an interface, in which the results with the answer to the question raised by the nurse are visualized, as shown in Figure 6. 
Figure 6 - ES Question Interface Braden Scale

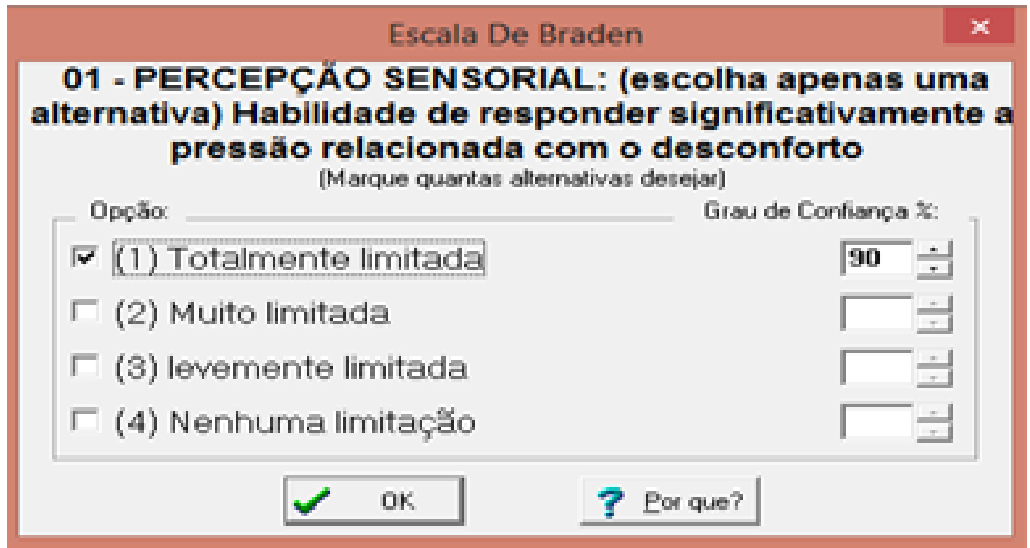

Source: Authors (2019).

Inferring at the end of this process an interface, which visualizes the results with the answer to the question raised by the nurse, as shown in Figure 7.

Figure 7 - ES Result Interface Braden Scale

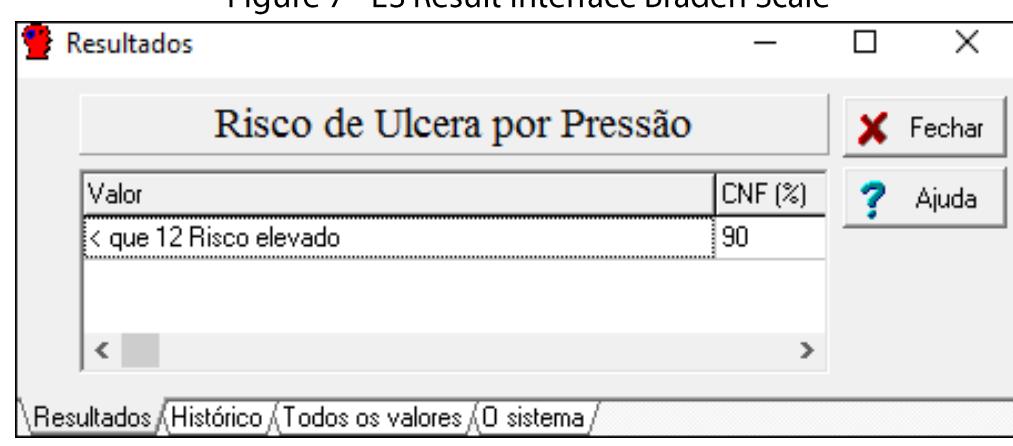

Source: Authors (2019).

In the Braden Scale module, the user visualizes a question interface, which generates new windows until all the questions raised are answered. After this step, the results appear in a new interface, which is composed by the following tabs: query results, all values, containing the data that were entered in the system, and the history through which it is possible to evaluate how and why the system arrived at the proposed result, as shown in Figure 8. 
Figure 8 - ES Result Interface History (Braden Scale)

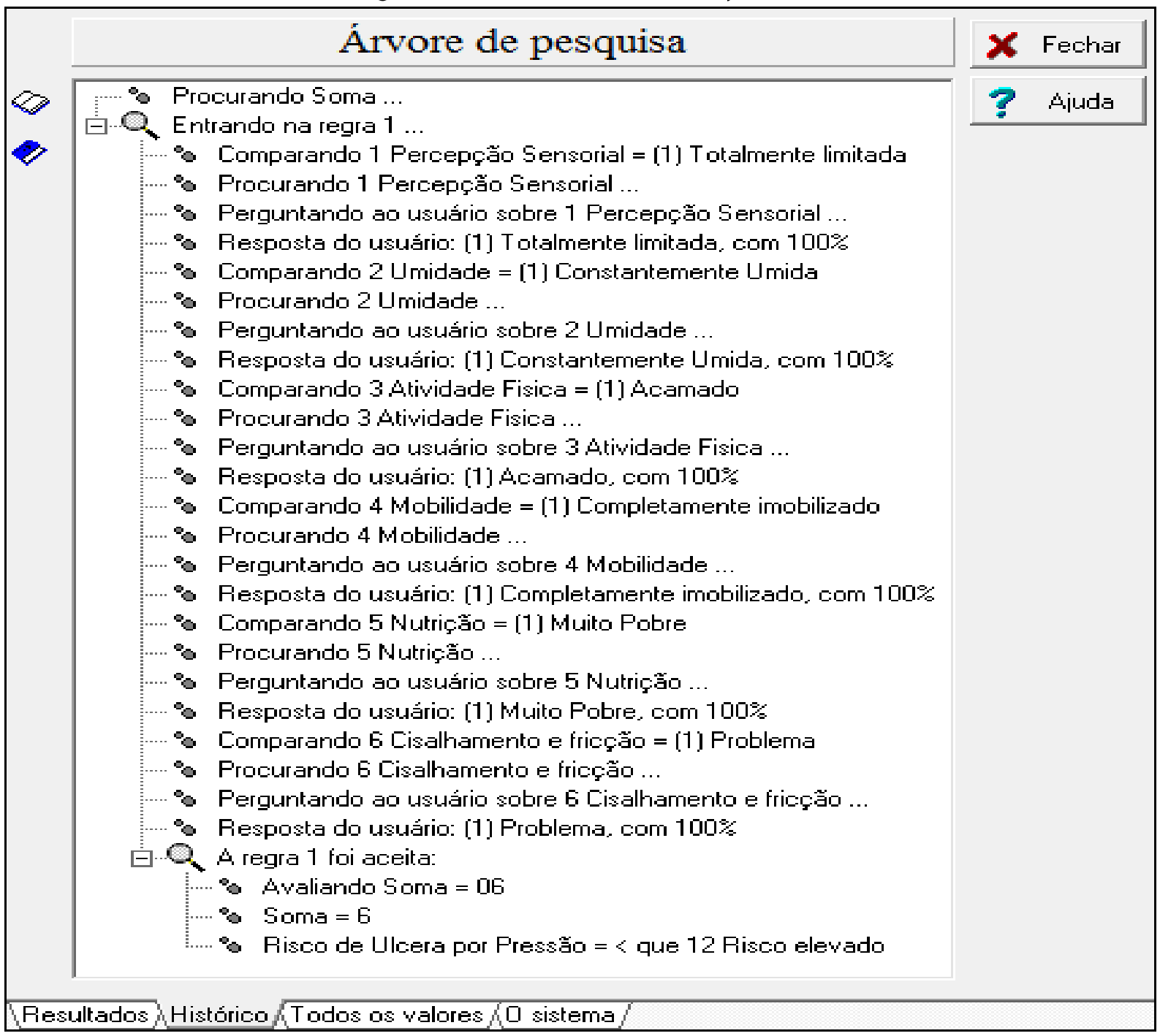

Source: Authors (2019).

The same process occurs during the use of the Glasgow scale module, which opens new windows until all the conditions are met to answer the question raised, as shown in Figure 9.

Figure 9 - ES Scale Glasgow Interface questions

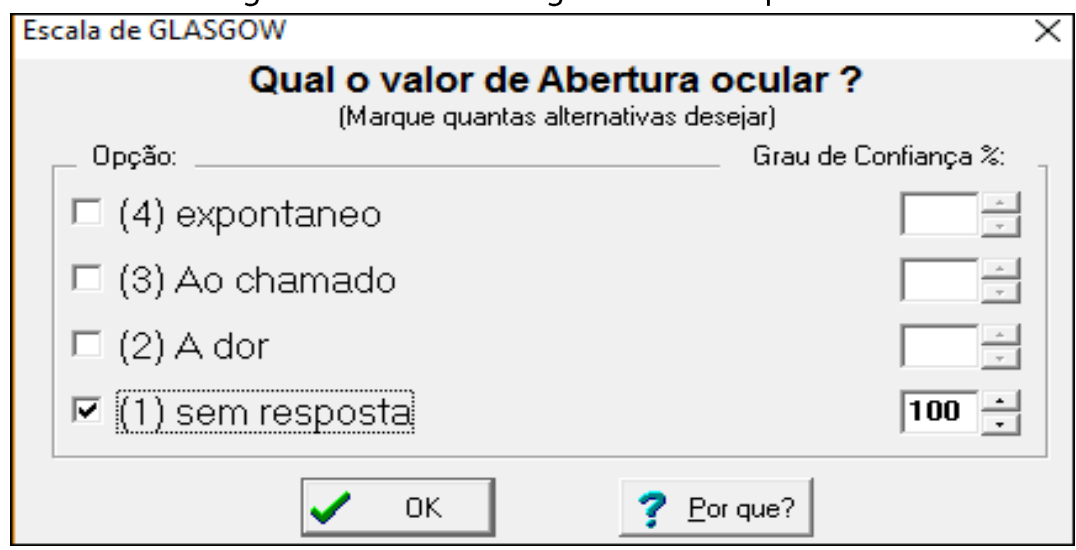

Source: Authors (2019). 
Inferring at the end of this process an interface, in which the results with the answer to the question raised by the nurse are visualized, as shown in Figure 10.

Figure 10 - Glasgow Scale ES Result Interface

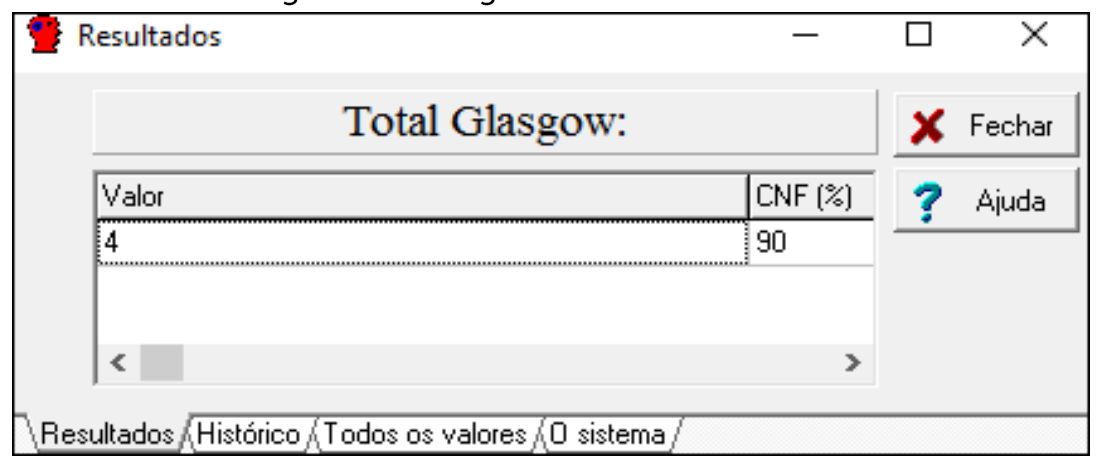

Source: Authors (2019).

The same process reported on the Braden scale occurs on the Glasgow scale. In Figure 11, you can see the result of the questions generated by the system.

Figure 11 - ES result interface history (Glasgow Scale)

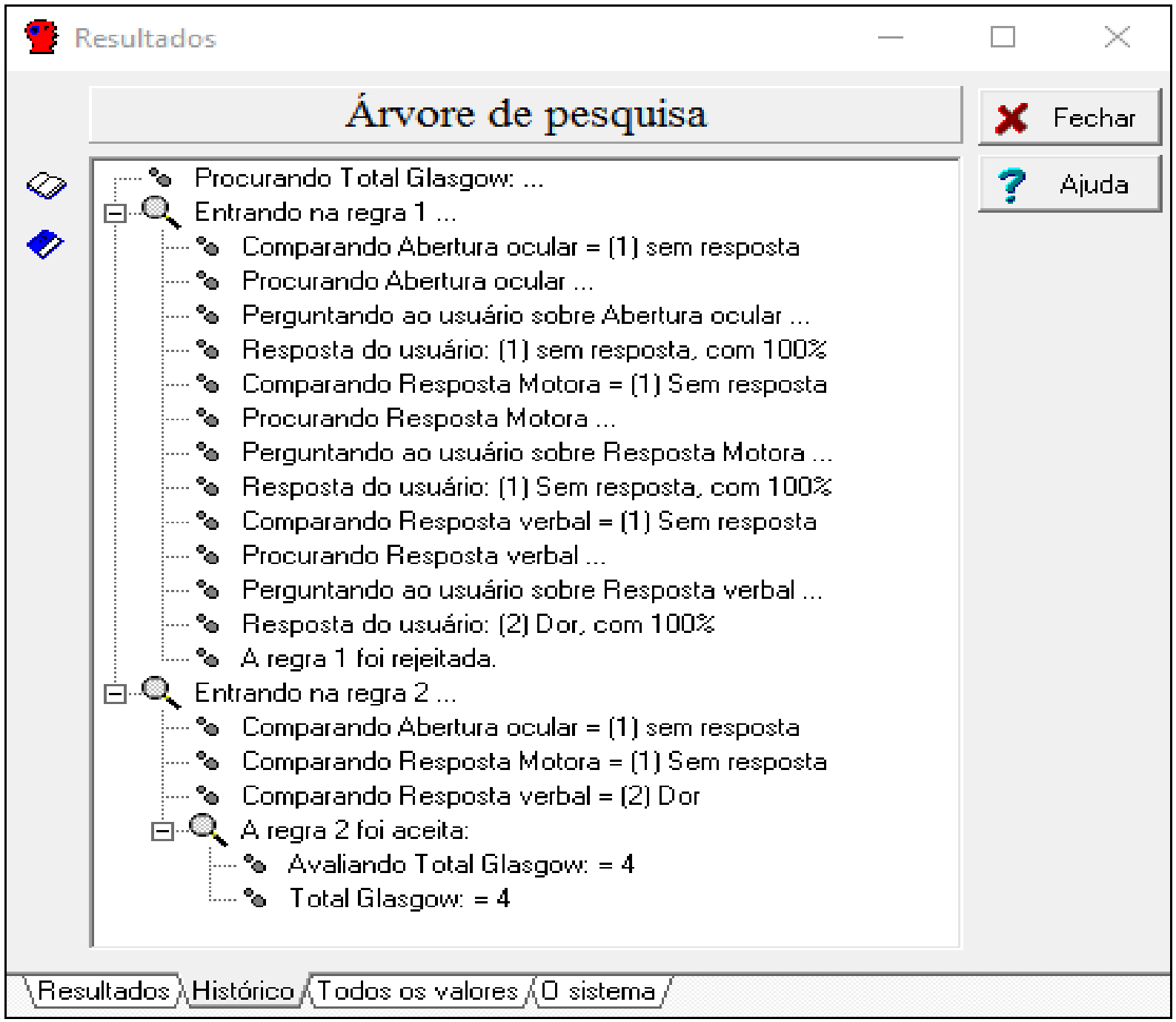

Source: Authors (2019). 
Once the Glasgow and Braden scale metrics in the computerized nursing process are inferred, the next step is the insertion of the diagnosis, from a series of options available in the system, as well as suggestions for prescribing and treating nursing, as shown in Figure 12.

Figure 12 - Nursing Prescription Interface

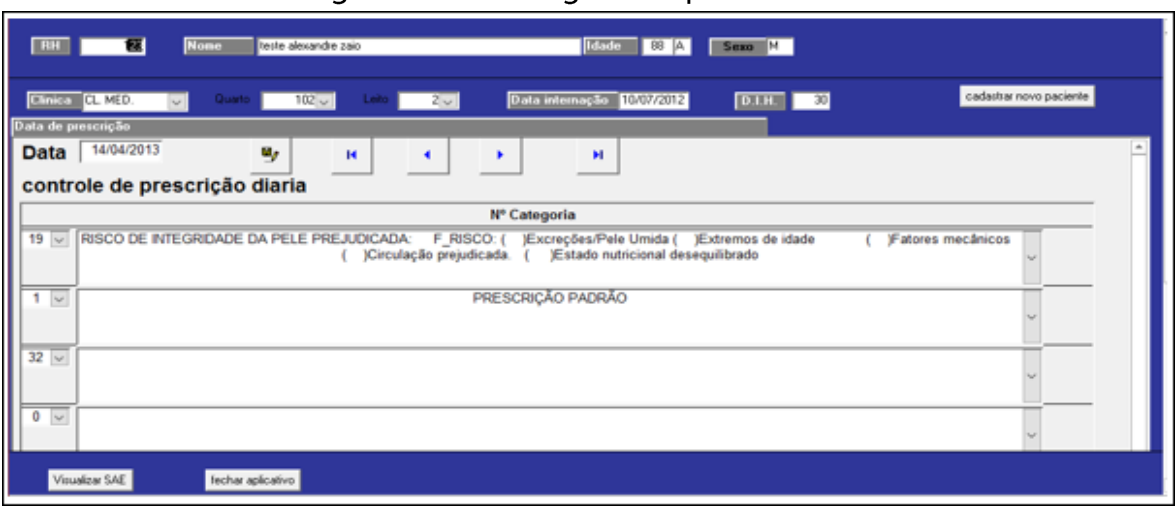

Source: Authors (2019).

Accepting the suggestions and making the necessary changes, as decided by the nurse, the system generates the nursing prescription, as shown in Figure 13.

Figure 13 - Nursing prescription generated by the system

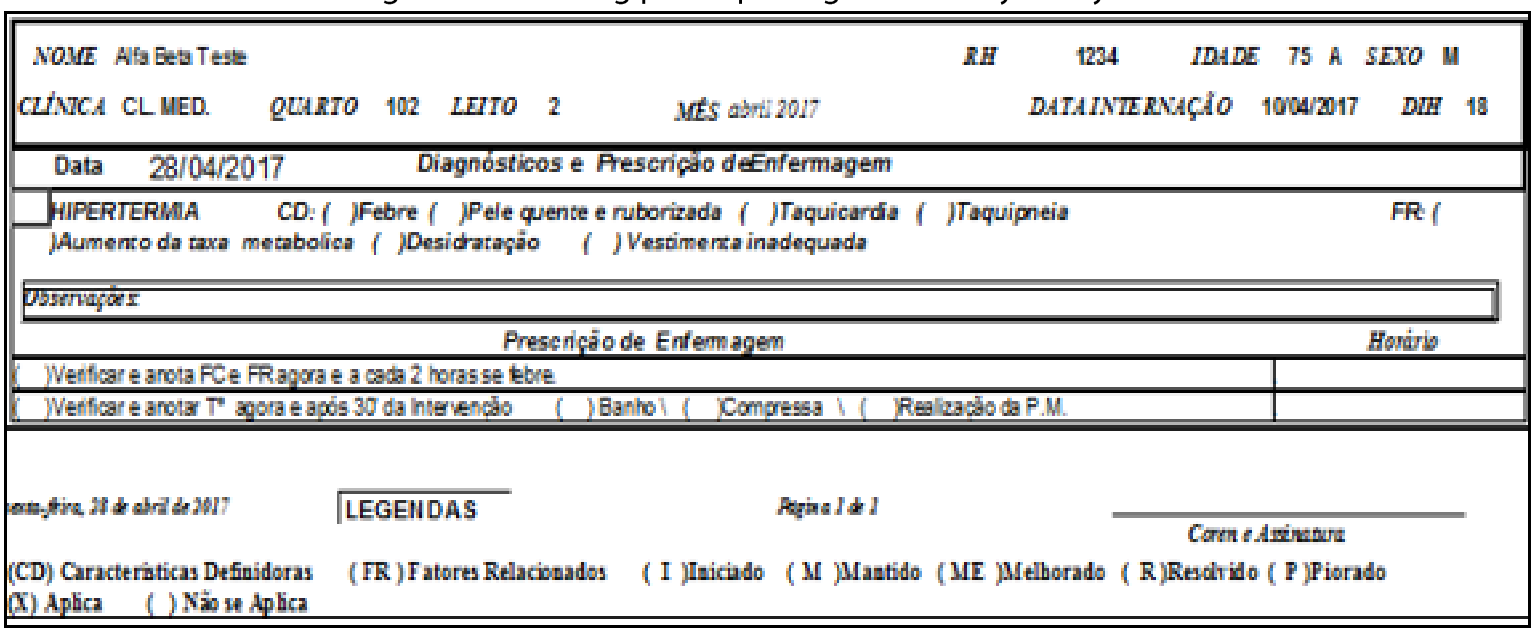

Source: Authors (2019).

Once implemented the decision support ES with the Glasgow and Braden Scales, and the computerized nursing process, the following results were achieved: optimization of the nursing process application time; standardization of patient assessment, prescription, care and schedules; ease of patient continuity of treatment, even when transferred to another ward; improvement in expert nurse assertiveness and measurement of Glasgow and Braden scales; possibility of monitoring and auditing of the whole process by nursing professionals; validation and approval of the ES knowledge base by specialists from both the hospital and external consultants.

\section{CONCLUSION}

With the application of the computerized nursing process, the Brazilian Public Hospital care was standardized, facilitating the continuity of the patient's treatment, even when transferred to another clinic. The computer system has standardized all nursing-related processes throughout the institution, including case registration, assessment, care delivery, prescriptions, and schedules, thus fully achieving the aims. 
With this work, it was also evidenced that the use of ES guaranteed greater assertiveness of nurses during the decision-making process by collecting signs and symptoms and measuring them through the Glasgow and Braden scales.

To validate and analyze the results, the research was based on the nurses' feedback. Thus, despite the lack of previous indicators, it was found that the nurse's gain in efficiency and effectiveness was assisted by a computer system supported by an ES. One of the biggest indications of this improvement was the reduction in the evaluation and prescription time of NP, from 20 minutes to 7, on average.

It was evident that the availability of the computerized nursing process with the ES modules brought major improvements to the system, having greater impact on the history and evolution of nursing.

A limitation is the fact that the application was performed in only one hospital and the absence of a mobile interface (cell phones and tablets) to access the system during the physical examination, thus reducing rework.

It is worth highlighting that the main challenge to be overcome was in the implementation of the computerized nursing process was the initial resistance presented by some nurses to use computer systems.

Another highlight was the difficulty for nurses to use a computational device beside the bed during the physical examination of the patient. This situation, which according to some nurses generated rework because they needed to make notes of the physical exam on paper and then transcribe them the system, which generated rework.

It is suggested as a continuity of this work, the implementation of the computerized nursing process in other health units in order to attend a larger number of patients and, consequently, a greater range of diagnoses. It is also suggested to develop an interface with mobile devices to be used near the patient's bedside.

Finally, with regard to $\mathrm{SE}$, it is suggested the application of another Al technique such as Case Based Reasoning (CBR) when considering a scenario of cases on a case basis and no longer on knowledge. In this way, the proposed technique would automatically update its database.

\section{REFERENCES}

ALFARO-LEFEVRE, Rosalinda. Aplicação do Processo de Enfermagem: Fundamentos para o raciocínio clínico. 8. ed. Porto Alegre: Artmed, 2014.

BUTCHER, Howard K. et al. Nursing Interventions classification (NIC)-E-Book. USA: Elsevier Health Sciences, 2018.

COFEN. Resolução COFEN-358 de 15 de outubro de 2009. Dispõe sobre a sistematização da assistência de enfermagem e a implementação do processo de enfermagem em ambientes, públicos ou privados, em que ocorre o cuidado profissional de enfermagem. [2009]. Available in: http://www.cofen. gov.br/resoluo-cofen3582009_4384.html. Access at: 18 out. 2020.

DA SILVA REIS, Geísa et al. Sistematização da assistência de enfermagem: vantagens e dificuldades na implantação/Systematization of nursing care: advantages and difficulties in implementation. Arquivos Médicos dos Hospitais e da Faculdade de Ciências Médicas da Santa Casa de São Paulo, v. 61, n. 3, p. 128-132, 2016.

DOMINGOS, Camila Santana et al. A aplicação do processo de enfermagem informatizado: revisão integrativa. Enfermería Global, v. 16, n. 4, p. 603-652, 2017.

DRABLE, Rosana Gama; MOL, Antonio Carlos de Abreu; LEGEY, Ana Paula. Avaliação do uso da lógica nebulosa para previsão de risco de Papiloma Vírus Humano. RECIIS - Rev. Eletron. de Comun. Inf. Inov. Saúde, v. 8, n. 3, p. 344-358, 2014.

DYMOVA, Ludmila; SEVASTJANOV, Pavel; KACZMAREK, Krzysztof. A Forex trading expert system based on a new approach to the rule-base evidential reasoning. Expert Systems with Applications, n. 51, p. 1-13, 2016. DOI doi.org/10.1016/j.eswa.2015.12.028. 
ESFANDIARI, Nura; BABAVALIAN, Mohammad Reza; MOGHADAM, Amir-Masoud Eftekhari; TABAR, Vahid Kashani. Knowledge discovery in medicine: Current issue and future trend. Expert Systems with Applications, v. 41, n. 9, p. 4434-4463, 2014.

GARCIA, Telma Ribeiro et al. Classificação Internacional para a Prática de Enfermagem CIPE (R): Versão 2019/2020. Porto Alegre: Artmed Editora, 2020.

GIL, Antonio Carlos. Como elaborar projetos de pesquisa. . ed. São Paulo: Atlas, 2002.

GOMES, Flávia Sampaio Latini; BASTOS, Marisa Antonini Ribeiro; MATOZINHOS, Fernanda Penido; TEMPONI, Harieti Rotelli; VELÁSQUEZ-MELÉNDEZ, Gustavo. Avaliação de risco para úlcera por pressão em pacientes críticos. Revista da Escola de Enfermagem da USP, v. 45, n. 2, p. 313-318, 2011.

GUPTA, Swati; SINGHAL, Ritika. Fundamentals and characteristics of an expert system. International Journal on Recent and Innovation Trends in Computing and Communication, v. 1, n. 3, p. 110-113, 2013.

HAIKAL, Ludmila. Prevenção da dengue utilizando o sistema especialista para big data hadoop. Revista Academus, v. 5, n. 1, 2017.

HORTA, Wanda. Processo de Enfermagem. Rio de Janeiro: Guanabara Koogan, 2011.

KIM, Eun Jung et al. Analysis of the Contents and Importance of Clinical Practicum Education in Adult Health Nursing According to Nursing Intervention Classification (NIC) System. Health Communication, v. 13, n. 2, p. 205-216, 2018.

LIA, Laboratório de Inteligência Artificial (1999). Expert SINTA: uma ferramenta para criação de sistemas especialistas. Fortaleza: Universidade Federal do Ceará, 1999. Available in: www.lia.ufc.br. Access at: 18 out. 2020.

LUCENA, Amália de Fátima et al. Validation of Nursing Outcomes and Interventions to Older Adults Care with Risk or Frail Elderly Syndrome: Proposal of Linkages Among NOC, NIC, and NANDA-I to clinical practice. International journal of nursing knowledge, v. 30, n. 3, p. 147-153, 2018.

MAGOC, Tanja; MAGOC, Dejan. Neural network to identify individuals at health risk. International Journal of Artificial Intelligence \& Applications, v. 2, n. 2, p. 104-114, 2011. DOI 10.5121/ijaia.2011.2208.

MILLER, Anne; MOON, Brian; ANDERS, Shilo; WALDEN, Rachel; BROWN, Steven; MONTELLA, Diane. Integrating computerized clinical decision support systems into clinical work: A meta-synthesis of qualitative.

International Journal of Medical Informatics, v. 84, n. 12, p. 1009-1018, 2015.

MOORHEAD, Sue; JOHNSON, Marion; MAAS, Meridean; SWANSON, Elizabeth. NOC Classificação dos

Resultados de Enfermagem. 5. ed. Rio de Janeiro: Elsevier, 2015.

NASER, Samy Abu; ALHABBASH, Mohammed Male Infertility Expert System Diagnoses and Treatment. American Journal of Innovative Research and Applied Sciences, v. 2, n. 4, 2016.

NIKITAEV, V. G. et al. Expert System for Histological Diagnosis of Prostate Cancer. KnE Energy, p. 328-332-328$332,2018$.

OLIVEIRA, Raisa Leocadio; DIAS, Samya Raquel Soares; DE SOUSA, Jairo Edielson Rodrigues B. Use of scales in the assessment of pressure injury in critical patients/Utilização de escalas na avaliação de lesões por pressão em pacientes críticos/Utilización de escalas en la evaluación de lesiones por presión en pacientes. Revista de Enfermagem da UFPI, v. 7, n. 3, p. 54-60, 2018.

PANNU, Avneet. Survey on expert system and its research areas. International Journal of Engineering and Innovative Technology (IJEIT), v. 4, n. 10, p. 104-108, 2015. 
PALOMARES, Mariana Laura Esteves; MARQUES, Isaac Rosa. Contribuições dos sistemas computacionais na implantação da sistematização da assistência de enfermagem. Journal of Health Informatics, v. 2, n. 3, p. 7882, 2010.

PEEK, Niels; COMBI, Carlo; MARIN, Roque; BELLAZZI, Riccardo. Thirty years of artificial intelligence in medicine (AIME) conferences: A review of research themes. Artificial Intelligence in Medicine, n. 65, p. 61-73, 2015. DOI 10.1016/j.artmed.2015.07.003

PEREIRA, M. A.; SCHAEFER, M. B.; MARQUES, J. L. B. Remote expert system of support the prostate cancer diagnosis. In: ENGINEERING IN MEDICINE AND BIOLOGY SOCIETY, 26;; ANNUAL INTERNATIONAL CONFERENCE OF THE IEEE, 2., 2004, San Francisco, CA, USA. Proceedings [...]. San Francisco: IEEE, 2004. p. 3412-3415.

PEREIRA, Mariane Onofre; LUDVICH, Sabrina Cardoso; OMIZZOLO, Jaqueline Aparecida Erig. Segurança do paciente: prevenção de úlcera por pressão em unidade de terapia intensiva. Inova Saúde, v. 5, n. 2, p. 29-44, 2016.

RAMOS, Júnia Helena Furini; RODRIGUES, Rosangela da Costa; GONZAGA, Márcia Féldreman Nunes. Origem e importância da Sistematização da Assistência de Enfermagem (SAE). Revista Saúde em Foco, n. 10, p. 923936, 2018.

RITROVATO, Matteo; FAGGIANO, Francesco; TEDESCO, Giorgia; DERRICO, Pietro. Decision-oriented health technology assessment: One step forward in supporting the decision-making process in hospitals. Value in Health, v. 18, n. 4, p. 505-511, 2015.

SHORTLIFFE, Edward Hance. Computer-based medical consultations: MYCIN. 2. ed. New York: Elsevier, 2012.

SHORTLIFFE, Edward $\mathrm{H}$. Artificial intelligence in medicine: weighing the accomplishments, hype, and promise. Yearbook of medical informatics, v. 28, n. 1, p. 257, 2019.

SOUZA, Ademar Rosa de. Estudo comparativo avaliando três modalidades de diagnóstico médico: parecer médico, buscas no Google e sistema especialista de apoio à decisão médica. 2020. 99 f. Tese (Doutorado em Fisiopatologia em Clínica Médica) - Universidade Estadual Paulista Júlio de Mesquita Filho, São Paulo.

SURABENJAWONG, Usapan; SONMEETHONG, Weeraphon; NAKORNCHAI, Tanyaporn. Accuracy of Glasgow Coma Score and FOUR score: a prospective study in stroke patients at Siriraj hospital. J. Med. Assoc. Thail, v. 100, n. 9, 2017.

TEASDALE, Graham.; JENNETT, Bryan. Assessment of coma and impaired consciousness: a practical scale. The Lancet, v. 304, n. 7872, p. 81-84, 1974.

TEASDALE, G. M.; MURRAY, L. Revisiting the Glasgow coma scale and coma score. Intensive Care Med, v. 26, p. 153- 154, 2000. DOI 10.1007/s001340050037.

WAGNER, William. P. Trends in Expert System Development: A Longitudinal Content Analysis of Over Thirty Years of Expert System Case Studies. Expert Systems With Applications, n. 76, p. 85-96, 2017. DOI 10.1016/j.eswa.2017.01.028.

WEISS, S. M.; KULIKOWSKI, C. A. Guia prático para projetar sistemas especialistas. Rio de Janeiro: LTC Livros Técnicos e Científicos S.A, 1988.

WECHI, Jeane Silvestri et al. Escala de Braden: instrumento norteador para a prevenção de úlceras por pressão. Estima-Brazilian Journal of Enterostomal Therapy, v. 15, n. 3, p. 145-151, 2017. 